\title{
THE EARLIEST TRACE OF EURIPIDES IN SPANISH LITERATURE
}

\author{
From the Archive of María Rosa Lida de Malkiel
}

[While sifting through María Rosa Lida de Malkiel's archive in search of inedita of continued potential value to fellow workers, I chanced upon a six-page typescript entitled as above. On circumstantial evidence it is both easy and safe to hazard the guess that the undated piece represents the text of an invitational fifteen-minute ponencia, read at a modernlanguage or medievalist, or comparative-literature symposium, probably held somewhere in the mid or late 'fifties. A fuller, but somewhat differently skewed treatment of the same problem will be found in La originalidad artística de "La Celestina", pp. 332-338; and a mere allusion to it in Two Spanish Masterpieces, p. 62. It is possible but not demonstrable that an outline, draft, or preliminary version of this paper was written in spanish first; in any event, the piece was delivered in English and could well represent one of the earliest English-language ventilations of her ideas on Fernando de Rojas' masterpiece. The typescript preserved shows a few minor stylistic improvements suggested by myself at that time and apparently accepted by the invited speaker, as well as traces of her own polishing of the wording and or repeated practice reading; it has here been newly edited for enhanced smoothness. One is left wondering whether the author had any intention of converting this causerie, into a note or of expanding it into a fullfledged article, to make it more easily accessible to students, of reawakened concern with Greek Classics. Yakov Malkiel, University of California, Berkeley].

SPANISH LITERATURE is little given to imitation of the classics, particularly of the Greek. It can be affirmed that there is hardly any direct trace left by the Greek theater in spain until the 18th century, and then only in writings that are mediocre and less than characteristic, works that reflect, rather than Greece, the Italian or French enthusiasm over Greece:

Yet, the text in which I find the first trace of Euripides is unique in more than one way. I mean Celestina, written at the end of the 15 th century by two or more men of letters, principally by Fernando de Rojas, its only known 
author, who was a converted Jew, a Bachelor of Laws; he wrote that work in his youth and never composed any other. Its plot is extremely simple: Calisto, enamored of the noble lady Melibea, makes use of the old go-between Celestina for seducing her; the lovers meet and make love. On leaving, after a rendezvous, Calisto falls headlong down the ladder; and when Melibea sees her lover dead, she throws herself from the top of a tower. This plot extends over twenty-one acts because, truth to tell, what interested Fernando de Rojas was not so much the story itself, as the chance to represent, while making use of the most varied and original dramatic techniques, the specific setting--the city, its people, streets and buildings; life in the house of a Castilian nobleman, his family and servants, the love affairs and feasts of lackeys and ladies of easy virtue as well as the characters, not typified or didactic (as in the medieval theater), but full of Shakespearean individuality.

I use the parallel with shakespeare, not to praise Rojas--who needs no praise--but rather to describe his way of delineating characters. Rojas is at even greater pains than Shakespeare to show a character change from one extreme to another: Thus Melibea passes from the most rigid chastity to the most ardent intoxication with love. This change is wrought, or rather precipitated, by Celestina in two meetings. In the first (Act IV), she stirs Melibea's very complex soul--not just conventionally virginal--by disclosing to her, in a variety of very skillful ways, Calisto's passion. That same passion takes hold of the heart of Melibea who, admitting to herself her infatuation, prays to God for strength not to reveal it, but at the same time, has the old woman brought to her secretly to cure her of an illness she claims to have contracted. Celestina understands everything and forces Melibea to confess her love, spurring her on with Calisto's name which provokes in Melibea, each time that she hears it, an increasingly violent reaction (Act $X$ ). Now then: In the play Hippolytus by Euripides, the Nurse tries in vain to extort from Phaedra the secret of her illness and, finally, reminds her that on her health depend the fortunes of her two sons (1ines 3043121 . The Nurse interprets Phaedra's anguish as horror at seeing her sons dispossessed, and proceeds with her questions and entreaties until Phaedra agrees to a painful confession and begins to lament the fates of her mother Pasiphae and her sister Ariadne, including herself as the third victim. In the face of an utterly confused Nurse, who is unable to follow the thread of her account. Phaedra is torn between the relief of her confession and her horror at having revealed her secret. Phaedra then states that she has not succumbed without a struggle. In the meantime, the Nurse has recovered from her dismay and applies herself to satisfying the Queen's desire with the same tenacity as she displayed in detecting it. She now invokes the irresistible cosmic force of Aphrodite and gives her appropriate advice. 
The resemblance. between this dialogue and the scene cited from Celestina is startling: Both enamored women avoid mentioning the names of their lovers, forbid their mention, and are shocked when their collocutors nevertheless pronounce them. Before their final confession, both younger women take the time to request a definition of love; in either instance the older woman counselor defines it by opposites, in the manner traditional since sappho. In both plays one witnesses a major conflict between the willpower of the woman in love and the passion that overcomes them; in each one the conflict is acted out on the stage. On both occasions the artist manages to retain the viewer's or reader's sympathy for the heroine even though she lets herself be vanquished. Another element common to both plays is the presentation of the women in love, possessed by desire yet afraid of being "cured", and the equivocal verbal fencing in which they engage with their confidantes, appealing to the image of "sickness" to describe their passion, and of "remedy" apparently to indicate the medicine that might do away with it, but actually the means that may serve to satisfy it.

Yet, Rojas resisted the temptation to imitate literaliy the admirable scene from Hippolytus. There, the Nurse unintentionally drops the name that makes Phaedra shudder, and when she hears the latter utter it a second time, she, rather than the woman in love, bursts out in horror, even though very soon there after she becomes the accomplice of her lady's twisted passion. Rojas' deviations from this model are very significant: Celestina does not blindly utter Calisto's name; at an earlier meeting she observed its effect on Melibea, and now, far from stumbling upon it, she uses it with expert deftness. In Hippolytus, the opportune mention of the name is due to chance, set in motion by the loquacious Nurse; in the Spanish play, whose careful motivation leaves little to chance, Celestina proffers it with the deliberate intention of disturbing the young woman. For that reason, the name needs to be mentioned only twice in Euripides before a confession is obtained, whereas the Tragicomedia boasts a skillfully protracted climax.

With due allowance for the originality of the imitation, one cannot attribute it to mere coincidence, since Rojas emphasizes the mention of the name first by the stricken victim, then by the old woman, as a spur to extorting the confession. Celestina, reporting to Calisto about her first encounter with Melibea, says: "Wounded by the golden arrow, the sound of your name" and, on hearing Melibea's complaint, sarcastically inquires $(\underline{X}, 68)$ : "Is his name so evil that its very utterance brings poison with it?" Melibea herself confesses to Calisto at their first date: "Even though I struggled for many days to dissimulate it, I could not prevent that woman from discovering my desire once she repeated your sweet name...". Everything indicates that 
Rojas paid heightened attention to this use of the name-half magic, half psychological--, in fact which tends to confirm the assumption that he owed his inspiration directly to Euripides since, in this particular case, there happens to exist no intervening link provided by Latin literature. As a matter of fact, in the plautine Cistellaria two courtesans discuss the love afflicting one of them, pretending to refer to some ailment, but without anything quite like the incident of the name. On the other hand, Seneca's play Hippolvtus issues forth from a different tragedy by Euripides, one in which Phaedra directly confesses her love for her stepson. Thus, Seneca'a piece falls short of resorting to the mention of a name as a revelation of a passion.

Could Fernando de Rojas have known the Euripidean Hippolytus? At first sight it seems implausible that there should have occurred any direct imitation of Greek art at its most splendid in a spanish late-15th-century work, both because the influence of Greek on Spanish literature has, on balance, been so slight, and because the date is so early. That is why, when claudio Guillén first called my attention to the use of the name in both the Greek and the Spanish work, I was inclined to discard the possibility of intentional imitation. The oldest known edition of Celestina is of 1499; there may have existed an older printing. Aside from Act $I$, the play was composed between 1496 and 1499. The only edition of Euripides predating the 16 th century--according to information privately passed on to me by that distinguished Hellenist Alexander Turyn--is that by Laurenti Francisci de Alopa, printed in Florence ca. 1496, conceivably between 1496 and 1498 ; it actually included Hippolytus. I have so far been unable to examine a copy of that book in an effort to learn whether it contained a Latin version that could have facilitated the perusal of the Greek original in 15th-century Castile. But remember in this context that the dates supplied for the recovery, by Humanists, of ancient works are solely provisional. Witness the case of Chaucer, who demonstrably used Valerius Flaccus' Argonautica, allegedly "rediscovered" sixteen years after the death of the English poet. Similarly, that Spanish moralist of the early 14 th century, Don Juan Manuel, in his Libro infinido offered a parallel too close to have been fortuitous to words from the speech pro Archia, which Petrarch is independently known to have "discovered" in Liège at about the same time (1333). Since nothing has been ascertained about the intellectual life of Rojas, it is hardly worth our while to make conjectures about how he might have got to know Hippolytus, whether through some Humanist friends or via an intermediate Latin version.

In conclusion: Since direct or indirect familiarity with Euripides was chronologically not impossible at that juncture, and since the coincidences are so sharply profiled 
as to carry decisive weight, there is no alternative to admitting the influence of this tragedy on the earliest dramatic work of modern theater. This influence must, by all odds, rank as exceptional, since it was, generally, Seneca who furnished the favorite model for the learned theater. But is it not a fact that all the distinctive features of Celestina--its tragic conception of love in a bourgeois setting, its concrete, visual grasp of reality, its psychological skill in portraying characters--are equally exceptional?

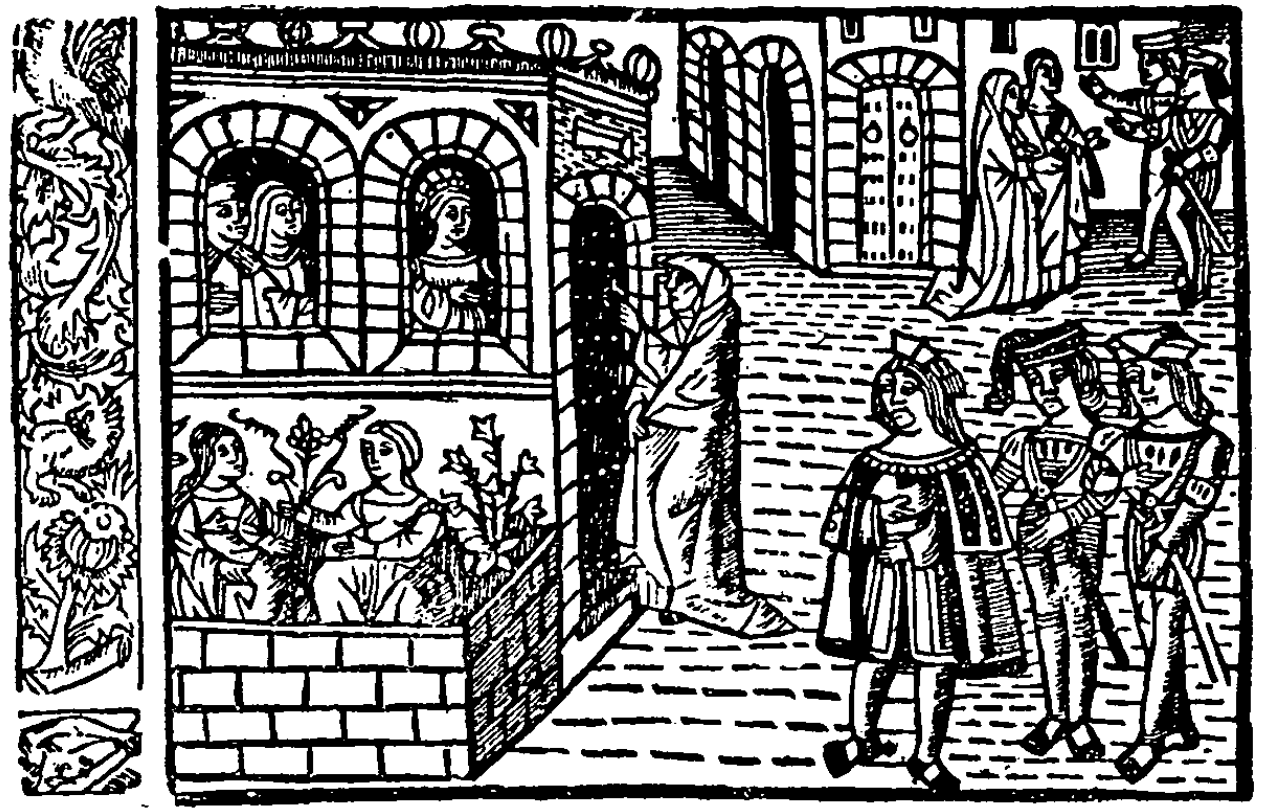

Tragicomedia de Calisto y Melibea. Barcelona, Carlos Amoros, 1525. 

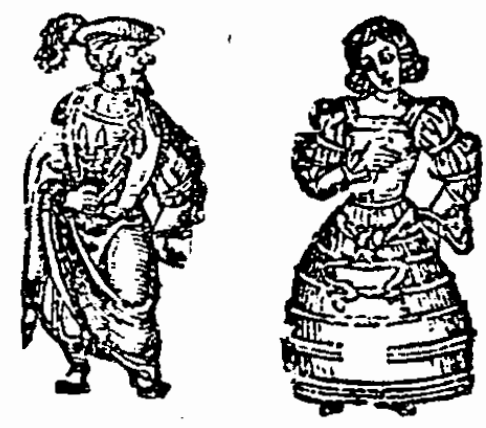

Dos figuras de la portada de la Tragicomedia impresa en Medina del Campo, 1530-1540.

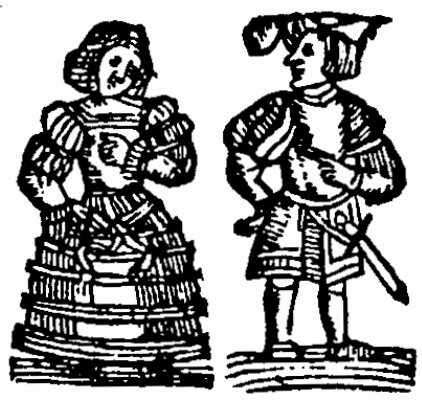

Dos figuras de la portada de la Silva de varios Romances Barcelona: Hubert Gotard, 1587 